\title{
Empirický přístup k morálnímu charakteru
}

\section{Empirical Approach to Moral Character}

\author{
Jan Brázdil
}

\begin{abstract}
Abstrakt
V této práci představuji a analyzuji stěžejní část diskuse, která vznikla mezi mysliteli inspirovanými psychologickým situacionismem a obhájci konceptu morálního charakteru, který se objevuje v aristotelské myšlenkové tradici. Jádrem této diskuse je otázka, zda zůstává tento koncept empiricky adekvátním ve světle nedávných poznatků sociální a kognitivní psychologie. Tedy zda představuje dostatečně významný determinant chování navzdory pưsobení situačních faktorů, jakými jsou sociální nátlak, momentální mentální nastavení či pouze špatné počasí. Přičemž musí být natolik významným determinantem, aby bylo smysluplné v praxi věnovat cenné zdroje na jeho kultivaci v rámci výchovy a vzdělání.
\end{abstract}

\section{Klíčová slova}

morální charakter, situacionismus, praktická moudrost, Milgramův experiment

\begin{abstract}
In this paper, I present and analyze the key part of the discussion that arose between the authors inspired by psychological situationism and the advocates of the concept of moral character that appears in the Aristotelian thought tradition. At the heart of this discussion is the question of whether this concept remains adequate despite recent findings of social and cognitive psychology. Whether it represents a significant determinant of behavior, withstanding various factors such as social pressure, momentary mental settings or even just something quite simple like bad weather. Its significance then must be high enough for it to be meaningful to devote valuable resources to its cultivation in practice.
\end{abstract}

\section{Keywords}

moral character, situationism, practical wisdom, Milgram experiment 


\section{Úvod}

Situacionisté v diskusi předkládají vlastní definici morálního charakteru ${ }^{1}$ a na základě výsledků relevantních psychologických experimentů soudí, že pozorování lidského jednání nepotvrdilo existenci takové dispozice, která by byla dostatečně rezistentní vůči situačním faktorům. Teoretikové ctnosti (čili obhájci aristotelského konceptu morálního charakteru v této diskusi) odmítají, že by výsledky experimentů mohly přesvědčivě vypovídat o přítomnosti či absenci morálního charakteru především proto, že situacionistická kritika podle nich pracuje s mylným konceptem. Situacionisté totiž upínají pozornost především na behaviorální stránku, dle teoretiků ctnosti tak opomíjí zásadnější aspekty morálního charakteru, a v důsledku tak míjí cíl své kritiky. Aspektů, o kterých teoretikové ctnosti mluví, je více, tím zdaleka nejčastěǰsím a klíčovým je ale morální úsudek či rozvaha (tedy působení praktické moudrosti). $\mathrm{V}$ této práci se budu věnovat právě tomuto aspektu a $\mathrm{k}$ němu se vážící diskusi. Ve třech následujících kapitolách se krátce zmíním o podstatných stránkách diskuse, o problému spojeném s interpretací empirické evidence, o vztahu empirických a normativních otázek a o významu důkazního břemene. Poté již otevřu otázku po nutných a dostatečných aspektech morálního charakteru, kdy nejprve analyzuji situacionistické argumenty pro upřednostnění behaviorálního aspektu, abych mohl plynule přejít k argumentům teoretiků ctnosti a analýze důsledků, jaké má přijetí morálního úsudku jako nutné součásti morálního charakteru. Na závěr věnuji větší prostor argumentační analýze vztahující se k Milgramově experimentu, kolem kterého se rozrostla

1 Tázání po tom, jakou dispozicí „morální charakter“ je, jaké aspekty jsou jeho součástí a jakým způsobem se projevuje, je podstatným bodem celé diskuse. V této otázce se však prozatím nedošlo uspokojivé shody. Přijměme v rámci této práce toto obecné vymezení: morální charakter je v čase trvající dispozicí, díky níž její nositel reaguje relativně spolehlivě a adekvátním způsobem (napřr. statečně) ve všech relevantních situacích (např. ve všech nebezpečných situacích). V kontextu Aristotelovy etiky ctnosti, ve kterém se celá diskuse pohybuje, mluvíme o spojení určitého stupně mravní ctnosti (éthiké aretê) a praktické moudrosti (fronésis). Ovšem Aristotelés explicitně mluví spíše o ctnosti, tedy o morálním charakteru v pozitivním a vysoce kultivovaném smyslu, zatímco zde se diskuse týká morálního charakteru, kterým má disponovat většina lidí. Tento pojem sám nemusí mít nutně silně pozitivní náboj, připisujeme-li někomu morální charakter, nevypovídáme přímo o stupni, ale spíše o struktuře. Tvrdíme, že v morálních situacích funguje určitým způsobem, neříkáme ale nic o tom, jak moc spolehlivě (můžeme mluvit o dostatečně spolehlivém či dostatečně ctnostném charakteru). Když chceme vyjádřit pozitivní náboj, mluvíme o ctnostném charakteru nebo ctnostném člověku. Pojem „ctnost“ nakonec označuje nejen dobře kultivovaný morální charakter, ale také morální hodnotu (např. spravedlivý si cení spravedlnosti). 
stěžejní část diskuse týkající se morálního úsudku, stejně jako nezajímavější část této diskuse vůbec.

\section{Dostatečná evidence}

„Faktická data z experimentů jsou nesporná. Ale o čem experimenty vypovidaji, zůstává velmi kontroverzní. “2 Takto Robert Solomon ve svém krátkém komentáři vystihuje velmi podstatný rys této diskuse, na který se v argumentech často zapomíná. Pouhý fakt, že existují různé sféry vlivů (např. nálada, prostředí a sociální nátlak), které do nějaké míry determinují lidské chování, nemá v této diskusi žádnou důkazní váhu. Je to neproblematické tvrzení. Přijetí tohoto faktu je stále konzistentní s tvrzením, že vliv situačních faktorů na člověka není dostatečný k tomu, abychom odmítli morální charakter jako významný determinační faktor. Taková evidence může naopak vést k mínění, že apel na morální charakter při výchově není dostatečný, že morální charakter není mezi lidmi upevněn natolik, aby odolal popisovaným vlivům, a proto je třeba jeho kultivaci věnovat více zdrojů. Celá diskuse tak neustále krouží kolem otázky po dostatečnosti: Představuje morální charakter běžného člověka dostatečně slabý vliv na to, abychom se vzdali snah o jeho kultivaci a hledali alternativu, jak se vyrovnat s působením situačních faktorů? To nás přivádí $\mathrm{k}$ dalším dvěma bodům.

\section{Otázka empirická a normativní}

Ve velké části diskuse je kladena otázka po empirické adekvátnosti morálního charakteru, tj. zda pro nás představuje adekvátní deskripci popisující lidské morální chování. Adekvátnost morálního charakteru je však na několika místech zkoumána také ve smyslu normativním, kdy je chápán jako ideál, ke kterému bychom měli ve svém kognitivním a emocionálním vývoji směřovat. Tento pohled může být pro mnohé dokonce přirozenější, přeci jen jde o etickou teorii spíše než o psychologickou. Proč tedy nakonec nestačí upozornit na normativní aspekt, a vyhnout se tak celé diskusi o empirické

2 Robert Solomon, What's Character Got to Do with It?, Philosophy and Phenomenological Research 71, 2005, č. 3, s. 653 (kurzívou zvýraznil JB). 
adekvátnosti? Proč by nás mělo zajímat aktuální množství ctnostných ve světě, když je nám pouze předkládán ideál, kterého máme dosáhnout?

Problém spočívá v tom, že normativní teorie by byla přinejmenším problematická, pokud by předpokládala psychologickou realizovatelnost ctnostného charakteru u většiny, navzdory velmi nízkému aktuálnímu zastoupení mezi lidmi. ${ }^{3}$ Taková teorie by na sebe brala důkazní břemeno a musela by předložit dobré důvody, proč je tato psychologicky adekvátni dispozice v současné společnosti realizována $\mathrm{v}$ tak malé míře. ${ }^{4} \mathrm{Je}$ výchova potřebná $\mathrm{k}$ získání této dispozice natolik odlišná od běžné morální výchovy? Brání nějaký společenský vliv jejímu nabytî́? Tak či onak, výrazný nesoulad mezi požadovaným a současným stavem by implikoval vážnou námitku z normativní neadekvátnosti. Bud' by totiž byly velké nároky kladeny na člověka, nebo na rekonstrukci společnosti, ve které je vychováván a ve které působí.

Odmítneme-li naopak předpoklad, že by ctnostný charakter měl být dostupný většině lidí, a připustíme-li, že jej mohou nabýt pouze výjimeční lidé, nemusíme se prŕliš zajímat o diskusi týkající se empirické adekvátnosti (pokud by experimenty nevyloučily existenci i onoho malého množství ctnostných). Taková interpretace Aristotelovy etické teorie či taková neo-aristotelská teorie však v užší diskusi zastoupena není.

\section{Důkazní břemeno}

Při obhajobě empirické adekvátnosti morálního charakteru jsou teoretikové ctnosti ve výhodě. Situacionismus předkládá neintuitivní tvrzení, že lidské chování je determinováno situací v mnohem větší míře, než je většina $\mathrm{z}$ nás ochotna připustit. Tedy důkazní břemeno je na straně situacionistů. To mimo jiné znamená, že interpretace empirických dat podporujících situacionistické stanovisko nemůže být přijata jako dostačující důkaz, je-li předložena stejně přesvědčivá interpretace, která pravdivost tohoto stanoviska nepodporuje. Teoretikové ctnosti tak nemusejí dokázat, že v současnosti existuje dostatek lidí s ctnostným charakterem, ani že situacionistická interpretace empirických dat je nutně chybná, nepředložíli nejprve situacionisté přesvědčivou evidenci o opaku. Zatímco situacionisté jsou důkazním břemenem zavázáni

3 Viz Julia Annas, Intelligent virtue, New York: Oxford University Press 2011, s. 173.

4 Viz John Doris - Stephen Stich, As a matter of fact: Empirical perspectives on ethics, in Frank Jackson - Michael Smith, The Oxford handbook of contemporary philosophy, Oxford: Oxford University Press 2005, s. 121. 
k podání takových interpretací, které budou jednak podporovat závěr a jednak budou přesvědčivější než interpretace oponentů.

\section{Morální charakter jako behaviorální dispozice}

Společnou strategií teoretiků ctnosti při vyrovnávání se se situacionistickou kritikou je identifikace některých nutných aspektů morálního charakteru a následné zpochybnění způsobilosti předložených experimentů k testování na př́ítomnost takto pojaté dispozice. Situacionisté tak dle teoretiků ctnosti míjejí či zaměňují cíl své kritiky, nebot’ evidence, kterou předkládají, jednak příliš akcentuje behaviorální složku a jednak nebere v potaz specifické a nutné aspekty morálního charakteru, v diskusi označované jako vnitřní stavy (inner states), jako protiváhu ke vnějšímu a zjevnému chování (overt behavior). Situacionisté sledují oblast lidského jednání či prožívání, ve které se tyto aspekty neobjevují vůbec, nebo jen částečně.

Jaké jsou tyto nutné aspekty? Rachana Kamtekarová načrtává tř̌i oblasti působnosti morálního charakteru: úsudek, emoce a jednání (judgment nebo reason, feeling, action). ${ }^{5}$ Situacionisté berou v poraz emoce a jednání, teoretikové ctnosti však tvrdí, že nejpodstatnější je právě rozvaha či úsudek. Julia Annasová opakovaně upozorňuje, že morální charakter není nereflektovaný a nekritický návyk, automatický reflex, afekt či časem zautomatizovaná a bezmyšlenkovitá činnost. Morální charakter je dispozicí ,jednat na základě úsudku“ (disposition to act on reasons). ${ }^{6}$ Dokonale ctnostný bude vždy jednat na základě správného úsudku (orthos logos). Otázky po rezistenci či spolehlivosti morálního charakteru by tak měly vždy směřovat $k$ jeho schopnosti vytvářet co nejlepší úsudek a řídit se jím. Evidence, která ignoruje tento požadavek, zjevně nemůže být zcela adekvátní. Správný úsudek je pak výsledkem práce jedné z rozumových ctností, praktické moudrosti (practical wisdom, fronésis).

Přijetí praktické moudrosti jako součásti morálního charakteru vskutku vede k problémům ohledně adekvátnosti situacionistické evidence, kterým se však budu věnovat až v následující kapitole. Nejprve si představme situacionistickou reakci na tuto námitku. John Doris, přední obhájce situacionistické

5 Viz Rachana Kamtekar, Situationism and Virtue Ethics on the Content of Our Character, Ethics 114, 2004, č. 3, s. 477.

6 Viz J. Annas, Comments on John Doris's „Lack of Character“, Philosophy and Phenomenological Research 71, 2005, č. 3, s. 637-638; J. Annas, Virtue Ethics, in David Copp (ed.), The Oxford handbook of ethical theory, New York: Oxford University Press 2006, s. 516-517. 
pozice, po velkou část diskuse odmítá, že by cokoli jiného než zjevné jednání mohlo být adekvátním ukazatelem morálního charakteru. Pro toto stanovisko udává tři důvody. Za prvé, apel na vnější jednání je přítomen jak u Aristotela, ${ }^{7}$ tak u mnohých etiků ctnosti. ${ }^{8}$ Za druhé, z naší běžné morální perspektivy bychom člověku, který nesplňuje tuto podmínku (tj. selhává v přenesení svých dobrých záměrů k činům), nepřipsali ctnostný charakter. Teoretikové ctnosti tak s touto tezí přijímají také důkazní břemeno a podrývají normativní adekvátnost etiky ctnosti. ${ }^{9}$ Za třetí, pokud má být morální charakter vykazatelný pouze na základě vnitřních stavů bez ohledu na vnější jednání, pak je teorie asociovaná s touto koncepcí empiricky nefalsifikovatelná. ${ }^{10}$ Pokud má však apel na vnitřní stavy znamenat pouze pravděpodobnostní výchylku mezi mentálními procesy a jednáním, pak tato námitka nepředstavuje žádný problém, nebot’ s pravděpodobnostní rezervou situacionistická kritika počítá, tedy předpokládá se několikaprocentní omylnost. ${ }^{11}$

Tyto důvody nicméně, jakkoli na první pohled přesvědčivé, trpí nedostatky. K prvnímu, Doris v př́ípadě Aristotela odkazuje na pasáž v Etice Nikomachově (1098b30-1099a5), která je dvojznačná, ${ }^{12}$ a zároveň odmítá Aristotelovo vyjádření, že o ctnosti vypovídá záměrná volba spíše než jednání samo. ${ }^{13} \mathrm{~V}$ případě autorů, na které se odkazuje, je věc složitější. Mnozí možná nepovažují propast mezi záměrnou volbou a jednáním za tak širokou. Je také třeba vzít $\mathrm{v}$ potaz, že tito autoři nepsali s ohledem na nuance, o které v této diskusi jde. K druhému, Doris nedoceňuje interpretační variabilitu. Teoretikové ctnosti dokazují, že subjekty v experimentech mohly mít dobré důvody, proč nejednat tak, jak experimentátoři očekávali (viz analýza Milgramova experimentu dále). Ač lze s Dorisem souhlasit, že člověk, který není schopen naplňovat své hodnoty, nemůže být považován za ctnostného (šlo by o člověka, v Aristotelo-

7 Viz J. Doris, Lack of character: personality and moral behavior, New York: Cambridge University Press 2002, s. 17.

8 Viz J. Doris, Persons, situations, and virtue ethics, Nous 32, 1998, s. 509.

9 Viz J. Doris, Lack of character..., s. 16; J. Doris, Replies: Evidence and Sensibility, Philosophy and Phenomenological Research 71, 2005, č. 3, s. 662-664.

10 Viz J. Doris, Lack of character..., s. 26; J. Doris, Replies: Evidence and Sensibility..., s. 664.

11 Viz J. Doris, Lack of character..., s. 19.

12 Aristotelés na tomto místě tvrdí, že „k ní náleží přiměřená činnost z hlediska zdatnosti“

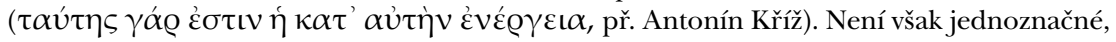
zda se přítomné zájmeno ženského rodu týká ctnosti, nebo blaženosti.

13 Viz J. Doris, Persons, situations, and virtue ethics..., s. 523, pozn. 25. Odkaz na Aristotelovo vyjádření se vztahuje k EN 1111b6-7. 
vých termínech, nezdrženlivého), nelze souhlasit s tím, že simulované situace v experimentech byly jednoznačné. Ke třetímu, pravděpodobnostní rezerva je v tomto případě nepřesná, bohatost vnitřních stavů nelze skrýt pod procentuální omylnost. Např. velmi milosrdný člověk, který je ale přesvědčen, že přijmout peníze je ponížením, bude při střetu s žebrákem „selhávat“ vždy, nikoli s pravděpodobností $p$. Koncept morálního charakteru na druhé straně neumožňuje stejným zpo̊sobem zpochybnit jakékoli empirické pozorování, problém s falsifikací je tu pouze tehdy, pokud experimenty nebudou dostatečně důmyslné, aby se vyhnuly podobným námitkám. Takové experimenty by musely být zřejmě finančně nákladnější a komplexnější, jak Doris sám poznamenává, ${ }^{14}$ ale tím hůře pro situacionismus, nikoli pro etiku ctnosti.

\section{Morální ambivalence situací}

Fakt, že experimenty neberou v potaz důvody, proč subjekty jednaly tak, jak jednaly, tj. na základě jakého pochopení situace jednaly, je často brán jako výtka. ${ }^{15}$ Ta však sama o sobě nic nevypovídá o adekvátnosti situacionistické evidence, vyžaduje proto párovou premisu. Teoretikové ctnosti připojují tvrzení, že situace, které experimenty tvoří, lze interpretovat i takovým způsobem, že „správné“ jednání (tj. takové, které experimentátoři či interpreti označili za adekvátní s ohledem $\mathrm{k}$ dané ctnosti), nemusí být subjekty považováno za skutečně správné. Okamžitou námitkou ze strany situacionistů může být, že taková interpretace simulované situace by byla zjevně vadná, ovlivněná situačními vlivy, a v důsledku prozrazující nedostatečnou rezistenci morálního charakteru. Teoretikové ctnosti ale tvrdí, že taková interpretace může být adekvátní a že hlavní rozdíl spočívá v rozdílném chápání toho, co je milosrdné, spravedlivé nebo obecněji ctnostné.

Annasová z této pozice kritizuje situacionistickou interpretaci experimentů, která experimentátorům přiznává absolutní autoritu v otázce, co skutečně je a co není správnou reakcí na předložené situace. ${ }^{16}$ Fakt, že právě experimentátoři tyto situace konstruovali, nic nemění na tom, že se staví nad etiku ctnosti, nad pomyslného Sókrata, který se po podstatě ctností teprve ptá.

14 Viz J. Doris, Lack of character..., s. 56.

15 Viz např. Gopal Sreenivasan, Errors about errors: Virtue theory and trait attribution, Mind 111, 2002, s. 58; J. Annas, Virtue Ethics and Social Psychology, A Priori 2, 2003, s. 24; R. Kamtekar, Situationism and Virtue Ethics..., s. 470.

16 Viz J. Annas, Virtue Ethics and Social Psychology..., s. 23. 
Proč by měl být psycholog v otázce ctnosti autoritou a proč by měl být názor subjektu lhostejný? Doris tuto námitku předjímá, z počátku nevidí problém v predikci jednání ctnostného člověka. ${ }^{17}$ Později odpovídá, že při sestavení experimentu je zkrátka nutné předem stanovit, jaké reakce mají být považovány za relevantní $\mathrm{k}$ připsání dispozice a že není třeba být zcela konceptuálně přesný. ${ }^{18}$ Poté ještě dodává, že určité reakce jsou „široce považovány za typický projev ctnosti“.. ${ }^{19}$ Annasová se však ptá, jak vůbec můžeme činit predikce ctnostného jednání bez dobrého porozumění ctnosti. Nebo naopak, jak můžeme dopředu znát „celý rozsah“ situací, ve kterých je určité jednání adekvátní reakcí? ${ }^{20}$ Annasová takto směřuje k tvrzení, že i dokonale ctnostný mohl podle experimentátorových měřítek selhat. Slabší pozici prezentuje Kamtekarová, podle níž musíme přihlédnout k těm subjektům, které v experimentu selhaly (dle nastavených měřítek) kvůli jediné nedokonalosti charakteru a které bychom tak stále považovali za dostatečně ctnostné. Na témže místě a s odkazem na jeden z experimentů uvádí teoretický př́íklad poctivého člověka, který však odsuzuje testování jako formu nespravedlivého odměňování edukačně privilegovaných. ${ }^{21}$ Takový člověk si může velmi cenit poctivosti (ani ho proto nenapadne krást nebo lhát), ale při testu využije všech prostředků k nejlepšímu výsledku. Takového člověka bychom považovali za jednajícího konzistentně s vlastním chápáním dané ctnosti, aniž by byl vychýlen morálně irelevantními faktory. Ale způsob testování, který předkládají situacionisté, by nás vedl k závěru, že jeho nepoctivost při testu je selháním naplnit vlastní hodnoty (v důsledku vlivu situace).

Lze upozornit i na další aspekty morálního charakteru. Lidé mohou např. za vhodné považovat různé strategie, jak pomoci druhým (v aristotelském rámci mluvíme o části praktické moudrosti nazvané fronésis to pros telos). Štědrý může odmítnout dát almužnu chudému, protože se rozhodl své finance vložit do dlouhodobější pomoci chudým. Hodná vychovatelka může nepochválit dítě za usilovnou práci, protože má obavu, že by dítě fixovalo svou další činnost na očekávání odměny ve formě její pochvaly a přestalo by vidět hodnotu v úkolu samém.

17 Viz J. Doris, Persons, situations, and virtue ethics..., s. 522, pozn. 14.

18 Viz J. Doris, Lack of character..., s. 27.

19 Viz J. Doris, Replies: Evidence and Sensibility..., s. 662.

20 Viz J. Annas, Virtue Ethics and Social Psychology..., s. 33, pozn. 26; srov. Maria Merritt, Virtue Ethics and Situationist Personality Psychology, Ethical Theory and Moral Practice 3, 2000, č. 4, s. 365 .

21 Viz R. Kamtekar, Situationism and Virtue Ethics..., s. 476-477. 
Situacionisté se vưči těmto námitkám mohou bránit dvěma způsoby. Za prvé, mnoho námitek tohoto typu je vážně zpochybněno s odkazem na kontrolní skupinu. Pokud kontrolní skupina (tj. skupina subjektů, která nebyla vystavena situačním faktorům) jednala odlišně od hlavní testované skupiny, pak je přesvědčivé tvrdit, že za změnou chování stojí právě situační faktor a nic jiného. Za druhé, situace byly konstruovány tak, aby byly nesnadné, ale s ohledem na správné řešení zároveň jednoznačné. Zůstává tedy otázka, jaké mohly mít subjekty důvody k tomu, aby jednaly způsobem, jaký experimentátoři považovali za neadekvátní? Doris připouští, že morální charakter je flexibilní a nemůžeme od něj očekávat stále též šablonovité jednání, ale vždy jen náležité vzhledem k dané situaci, přesto chápe situace v experimentech za normativně neproblematické. ${ }^{22}$ Abych ukázal, jak se tato otázka řeší na konkrétních případech, reflektuji v následující kapitole na sporu o Milgramův experiment oba stěžejní body argumentace, tedy jak otázku kontrolní skupiny, tak problém morální ambivalence simulovaných situací.

\section{Milgramův experiment}

V Milgramově experimentu poslušnosti vưči autoritě zájemci souhlasili s účastí na studii týkající se problému učení a paměti na Yale University. Při příchodu byli instruováni experimentátorem ohledně jejich přidělené funkce. Měli se stát učitelem (teacher), kontrolovat správnost odpovědí pokusného „subjektu“ či studenta (learner) a v případě špatné odpovědi mu způsobit elektrický šok, který mohl být „bolestivý, ale nikoli nebezpečný“ (při otázání tuto informaci experimentátor opakoval i během experimentu). S každou další chybnou odpovědí (nebo absencí odpovědi) měli přejít k šokům o 15 voltů silnějším. Ve skutečnosti byli právě oni subjekty tohoto experimentu. Student, umístěný ve vedlejší místnosti, záměrně chyboval, a subjekt tak měl postupně přejít až k 450 voltům označeným značkou „XXX“. Během testu si student začal stěžovat na bolesti u srdce a důrazně po experimentátorovi žádal ukončení experimentu. Dle původního návrhu (r. 1963) přestal student odpovídat po 300 voltovém šoku. Při stížnosti experimentátor subjektu opakoval některou z frází typu ,je nutné, abyste v experimentu pokračoval“ nebo „prosím pokračujte“. Pod vlivem těchto okolností 26 ze 40 subjektů pokračovalo až do konce, zbylých 14 odmítlo pokračovat v rozmezí 300 až 450

22 Viz J. Doris, Replies: Evidence and Sensibility..., s. 662-663. 
voltů (tedy všech 40 pokračovalo alespoň do momentu, kdy student přestal odpovídat). Při replikacích (r. 1974) se změnami v provedení experimentu se čísla lišila, potvrzovala však původní výsledek. ${ }^{23}$

Jako v jiných stěžejních experimentech, tak i zde jsou k dispozici kontrolní skupiny, díky kterým lze zúžit okruh relevantních faktorů. Kromě běžných kontrolních skupin tvořených subjekty, které podstoupily obdobné experimenty, vždy s několika změnami, Milgram provedl také před-experimentální průzkum. ${ }^{24}$ Lidem v této skupině byl položen dotaz, jak by se v takové situaci zachovali. Daniel Russell, jeden z významných obhájců situacionistické pozice, připouští, že celá situace může vypadat jako morální dilema, ale upozorňuje, že experiment byl nastaven tak, aby soucit s trpícím představoval jednoznačně vyšší hodnotu než jakýkoli závazek vưči experimentátorovi. ${ }^{25}$ Úspěšné naplnění tohoto záměru mělo být podpořeno důkazem, jímž měly být právě výsledky z před-experimentálního výzkumu, ve kterém nikdo z dotázaných neuvedl, že by v experimentu pokračoval za hranici 300 voltů, většinou pak uváděli mnohem nižší hranice (tyto odpovědi jsou brány jako odraz našich běžných morálních hodnot). Pokud byl tedy experiment adekvátně nastaven, není možné se odvolávat na to, že je zde morální dilema mezi rovnocennými hodnotami. Subjekty, které měly dojem, že měly vyšší závazek než být milosrdný k nemocnému člověku, zjevně selhaly v identifikaci toho, co je morálně správné, jejich morální kompas byl vychýlen situačními faktory. ${ }^{26}$ Proti tomu Kamtekarová a Christine Swantonová namítají, že v této situaci došlo ke skutečnému a nesnadnému morálnímu dilematu mezi milosrdenstvím (compassion) vůči trpícímu a důvěrou (trust) či kooperaci (cooperativeness) s experimentátorem. ${ }^{27}$

23 Viz Stanley Milgram, Behavioral Study of obedience: A study of situational and dispositional variables in helping behavior, The Journal of Abnormal and Social Psychology 67, 1963, č. 4, s. 371-378; S. Milgram, Obedience to authority: an experimental view, London: Tavistock, 1974.

24 Viz S. Milgram, Obedience to authority..., s. 27-31.

25 Viz Daniel Russell, Practical Intelligence and the Virtues, New York: Oxford University Press, 2009, s. 283.

26 Viz tamtéź; John Sabini - Maury Silver, Lack of character? Situationism critiqued, Ethics 115, 2005, s. 547, pozn. 33, 552-553; M. Merritt a spol., Character, in The Moral Psychology Handbook, eds. J. Doris and the Moral Psychology Research Group, Oxford: Oxford University Press, 2010, s. 364-366; Jesse Prinz, The normativity challenge: Cultural psychology provides the real threat to virtue ethics, The Journal of Ethics 13, 2009, s. 126-127.

27 Viz Christine Swanton, Virtue ethics: a pluralistic view, New York: Oxford University Press, 2005, s. 30-31; R. Kamtekar, Situationism and Virtue Ethics..., s. 473. 
Debata na toto téma začíná kritikou ze strany teoretiků ctnosti, která napadá experiment pro příliš velké nároky, které jsou na subjekty kladeny. ${ }^{28}$ Doplněním této kritiky je apel na stres, vypjatost či rozpolcenost, které byly patrné, jak Milgram zaznamenal, u většiny subjektů. ${ }^{29}$ Subjekty se zjevně lišily ve svých reakcích na tuto situaci, a to mnoha expresivními způsoby. Přesto není tento rozsah reakcí situacionisty (jmenovitě Dorisem) reflektován, jednání subjektů je naopak popisováno týmž způsobem. Nad tímto se pozastavuje Kamtekarová, ale i Nomy Arpalyová, která až na tuto výjimku plně souhlasí s Dorisovým stanoviskem. ${ }^{30}$ Morální charakter je zjevně záležitostí stupně a mnohé subjekty, přestože nebyly s to odolat extrémním okolnostem, bychom pokládali za reprezentanty takového morálního charakteru, který dostatečně ospravedlňuje empirickou i normativní adekvátnost.

Doris přijímá, že zvláště obtížné situace by nebylo možné brát jako evidenci, odmítá však interpretaci, že by Milgramův experiment takovou situaci vytvářel. ${ }^{31}$ Při obhajobě svého stanoviska upozorňuje na fakt, že subjekt nebyl žádnými způsoby donucován, experimentátor na něj nevyvíjel nátlak a kdykoli mohl odejít bez hrozby jakékoli penalizace. ${ }^{32}$ Experimentátor na jednu stranu pevným hlasem opakoval, že $\mathrm{v}$ experimentu je potřeba pokračovat, nikdy však nebyl nezdvořilý či výhružný. ${ }^{33}$ Dle Dorise tak navzdory př́itomnému morálnímu závazku nemučit nevinného člověka subjekty pokračovaly v experimentu pouze na základě „slušného požádání experimentátora““. ${ }^{34} \mathrm{Ja}$ kákoli stupňovitost reakcí by pak zjevně nemohla být dokladem morálního

28 Viz např. J. Annas, Comments on John Doris‘s „Lack of Character“..., s. 636.

29 „Ve velkém množství př́ípadů stupeň napětí dosáhl extrémů, které jsou během socio-psychologických laboratorních studií vídány jen vzácně... Čtrnáct ze čtyřriceti subjektů projevilo znaky nervózního smíchu a úsměvu. Smích se zdál být zcela nevhodným, až bizarním.“ (S. Milgram, Behavioral Study of obedience..., s. 375, překlad JB). Chování mnoha subjektů implikovalo, že chtějí experiment ukončit, přesto pokračovaly jen s ojedinělými (a mírnými) protesty vůči experimentátorovi (viz tamtéž, s. 376-377).

30 Viz Kamtekar R., Situationism and Virtue Ethics..., s. 473-474; Nomy Arpaly - J. Doris, Comments on 'Lack of Character' by John Doris, Philosophy and Phenomenological Research 71, 2005, č. 3, s. 644 .

31 Viz J. Doris, Lack of character..., s. 39-42, 49. J. Doris, Replies: Evidence and Sensibility..., s. 657-658.

32 Srov. S. Milgram, Behavioral Study of obedience..., s. 376.

33 Viz tamtéż, s. 374.

34 J. Doris - S. Stich, Moral Psychology: Empirical Approaches, The Stanford Encyclopedia of Philosophy, 2006. Dostupné z: <https://plato.stanford.edu/archives/fall2014/entries/ moral-psych-emp/>. 
charakteru, nebot i ti, kteří se rozhodli ukončit experiment předčasně, neprojevili dostatečnou rezistenci vưči mírnému sociálnímu tlaku.

Nedostatkem této Dorisovy reakce je implicitní předpoklad, že slovní nátlak ze strany experimentátora je zde jediným relevantním faktorem, který mohl vytvářet vysoké nároky na subjekt. Brání tak svou pozici proti námitce, že byl subjekt experimentátorem donucen, nikoli však, že byl vystaven extrémnímu vlivu situace. Tím je ponechán prostor pro další kritiku. S tou přicházejí John Sabini a Maury Silver, kteří vycházejí z pozice experimentátora vůči subjektu jako institucionálního experta vůči laikovi. Subjekt se podle nich dostává do institucionálního rámce, ve kterém je sám cizincem, experimentátor je naopak zjevně někým, kdo by měl velmi dobře vědět, jak interpretovat události v tomto rámci. Dle této interpretace subjekt chápe experimentátora jako „průvodce“, přijímá jeho percepci a na jejím základě je do určité míry ochoten revidovat tu svou. Jako posílení této interpretace jsou podstatné dvě další informace. Za prvé, subjekty se experimentu účastnily $\mathrm{s}$ vědomím, že jej již absolvovalo mnoho lidí před nimi. Za druhé, experimentátor (tj. institucionální expert) nijak nereflektoval to, co subjekty mohly interpretovat jako nesmyslné ubližování, či dokonce mučení člověka. Neprojevil starost o člověka, který zřejmě dostává smrtící šoky, ani neměl pochopení pro obavy, které subjekt projevoval. Nežádal, nepřesvědčoval, nenutil, pouze klidným hlasem oznamoval, že je potřeba v experimentu pokračovat. Subjektu (tj. laikovi) tak nebyla dána žádná opora pro jeho interpretaci situace. Experiment, ve kterém je při každém testování mučen (či dokonce umučen) testovaný subjekt, zjevně nemohl dosáhnout tolika opakování; a experimentátor zjevně nepovažoval situaci ani za natolik problematickou, aby si žádala ujištění, že je vše v naprostém pořádku. Sabini a Silver naproti předešlé Dorisově námitce zdůrazňují, že jakékoli naléhání ze strany experimentátora na subjekt by prozrazovalo experimentátorovu nejistotu a následně snižilo míru poslušnosti subjektu. Sabini a Silver na alternativních verzích experimentu ukazují, jak významnou roli zde hraje absence jakékoli vnější podpory pro percepci subjektu. V jednom př́ípadě byl př́itomen druhý experimentátor, který zpochybňoval pobídku prvního, že je potřeba experiment dokončit. Jindy byl subjekt konfrontován s reakcí jiného účastníka experimentu, který odmítl pokračovat. V prvním případě všechny subjekty odmítly pokračovat s první vyslovenou pochybností, ve druhém zůstalo konformních jen $10 \%$. $\mathrm{S}$ projevem pochybnosti se výsledky experimentu zásadně mění. ${ }^{35}$

35 Viz J. Sabini - M. Silver, Lack of character?..., s. 550-552. 
Jádrem této interpretace je, že se zde subjekt ocitá ve zcela novém prostředí, ve kterém se děje něco, co pro něj nemůže být pochopitelné. Ti, kteří by událostem v tomto prostředí měli rozumět nejlépe, se chovají zcela proti očekávání a jakákoli opora pro interpretaci situace ze strany subjektu není př́ítomná. ${ }^{36}$ Jak tvrdí Sabini a Silver, subjekt má málo důvodů domnívat se, že je někomu skutečně ubližováno, tedy že je jeho interpretace situace správná. ${ }^{37}$

Zde se otevírá prostor pro morální dilema, nebot otázka po důvěře a kooperaci se nezdá být nemístná. Je smysluplné se ptát, zda od milosrdného člověka očekáváme důkladné prošetření každé možnosti ublížení, i za cenu snížení kooperace s ostatními. Zda chceme, aby za takových okolností i jako laik, který má dobré důvody domnívat se, že situaci nerozumí, zpochybňoval rozhodnutí experta. Sabini a Silver u subjektů tohoto experimentu objevují silný strach ze společenského zostuzení. ${ }^{38}$ Člověk často přijímá interpretaci od svého okolí, jen aby nemusel riskovat, že se znemožní. Tento strach lze pak v tomto rámci chápat jako adekvátní reakci vưči přehnané sociální smělosti (stejně jako strach ze smrti vůči přehnané smělosti v ohrožení života). Člověk, který se nebojí za takových okolností nejen vyjádřit, ale i rázně prosazovat svůj názor, bude možná překračovat přiměřenou míru nebojácnosti.

Jak ale $\mathrm{z}$ této pozice vysvětlit důkaz ve formě před-experimentálního průzkumu? ${ }^{39}$ Ten dokazuje pouze to, že (ani) zájemci o téma „poslušnost vůči autoritě“ nedokážou predikovat své jednání v takovém experimentu. Není ale jasné, jak tento závěr podporuje tezi o nepřítomnosti dobrých důvodů proč neposlechnout experimentátora. Nic nebrání tvrzení, že experiment nebyl dostatečně popsán nebo že odpovídající zkrátka nevzali v potaz všechny důvody. Ze zaznamenaných ústních odpovědí v před-experimentálním průzkumu není patrné, že by kdokoli vnímal na situaci cokoli zvláštního, nebo dokonce absurdního, ani že by viděl rozdíl mezi tím, jak by jednal on sám a jak by jednal jiný člověk. ${ }^{40}$ Přísně vzato, majíli tyto výpovědi skutečně

36 Překvapivě vhodnou ilustrací $\mathrm{k}$ této situaci mohou být známé romány a povídky Franze Kafky. Hlavní postava Zámku, Procesu a Proměny se ocitá právě v takových typech absurdních situací, ve kterých institucionální pravidla nabývají zcela nečekané a nepochopitelné formy.

Viz J. Sabini - M. Silver, Lack of character?..., s. 548, pozn. 35.

38 Viz tamtéž, s. 557.

39 Ten probíhal tak, že si účastníci přednášky (psychiatři, studenti, mimo-universitní zájemci) na téma Poslušnost autoritě vyslechli detailní popis tohoto experimentu a poté na grafické stupnici představující přístroj na udělování elektrických šoků označili sílu elektrického šoku, po kterém by odmítli pokračovat. (Viz S. Milgram, Obedience to authority..., s. 27-29.)

Viz tamtéž, s. 28, 30-31. 
plnit funkci kontrolní skupiny, pak rámují soubor relevantních faktorů pouze na oblast „být experimentu v plné míře a jakožto pokusný subjekt přítomen“. Takové zarámování je však stále př́liš široké, neurčuje nám rozhodující faktory, které výchylku v jednání způsobily. Mohlo jít o slabý sociální nátlak, jakým je požádání autoritativní osoby, ale stejně tak mohl hrát roli pocit důvěry, který subjekt nabyl s ohledem na klidný hlas experimentátora nebo na fakt, že není prvním účastníkem experimentu.

Situacionisté předkládají jinou, dalo by se říct, stejně obšírnou a přijatelnou interpretaci, ${ }^{41}$ ale opět platí, že (z důvodu důkazního břemene) není odkaz na takovou interpretaci relevantní, pokud existuje jiná, stejně nebo více přijatelná, která je konzistentní s konceptem morálního charakteru.

\section{Závěr}

Ve své práci jsem představil stěžejní moment diskuse mezi teoretiky ctnosti a situacionisty týkající se významu přijetí praktické rozvahy jako nutné podmínky morálního charakteru pro interpretaci empirických dat z oblasti sociální psychologie. Na analýze Milgramova experimentu jsem poté prezentoval, jakým způsobem je možné revidovat situacionistickou kritiku z pozice etiky ctnosti. Morální ambivalence simulovaných situací však není jediným sporným bodem spojeným s úvahami o vlivu rozvahy na naše chování, stejně jako Milgrami̊v experiment není jediným experimentem, který se týká problému morální ambivalence. Přijetí praktické rozvahy jako součásti morálního charakteru dále kupříkladu vede k vážným problémům pro experimenty, které jako subjekty přijali děti nebo dospívající, nebot tito nemohou mít ještě dostatečně rozvinuté chápání komplexních morálních hodnot jako je milosrdenství či spravedlnost. ${ }^{42}$ A do stejných nesnází se situacionistická pozice dostane, uvažujeme-li o morálním charakteru jakožto o neustále se vyvíjející dispozici, která je náchylná k revizi učiněných rozhodnutí za účelem zlepšení praktické rozvahy pro podobné situace, nebot každý subjekt podstupuje daný experiment pouze jednou. ${ }^{43}$

41 Viz M. Merritt a spol., Character..., s. 381-385.

42 Viz J. Annas, Virtue Ethics..., s. 516-519; srov. EN 1144b1-16.

43 Viz J. Annas, Intelligent virtue..., s. 16-32; Janina Angeli Magundayao, Dispositions and Skills: An Argument for Virtue Ethics against Situationism, Kritike: An Online Journal of Philosophy 7, 2013, č. 1, s. 98. 
Diskuse však v současnosti nejde touto cestou. Situacionisté po vytrvalém sporu, který nesměřoval ke zdárnému konci, změnili argumentační pozici a zaměřili se na přímou kritiku konceptu praktické moudrosti (a s ním spojených aristotelských pojmů jako „rozvaha“ či „úsudek“) jako normativně neadekvátního konceptu. Tedy takového, který je bud'to natolik obtížný pro běžného člověka, že by bylo nesmyslné věnovat naše zdroje $\mathrm{k}$ jeho kultivaci, nebo dokonce psychologicky zcela nemožný (čímž by byla zpětně napadena interpretace situacionistických experimentů z pozice prezentované výše). Celá diskuse se však tímto přesouvá do dílčích psychologických debat, do kterých teoretikové ctnosti spojení s počátky diskuse, bohužel, zatím vstupují jen nejistými kroky. Patrné ale je, že koncept praktické moudrosti, jak jej popisují situacionisté, je na první pohled odlišný od aristotelského. Diskuse se tak od sporu o morální charakter přesouvá ke sporu o správné chápání pojmu „praktická moudrost".

\section{Mgr. Jan Brázdil}

Katedra filozofie, Filozofická fakulta, Masarykova univerzita Arna Nováka 1, 60200 Brno, Česká republika 382430@mail.muni.cz 
